\title{
クラシックバレエダンサーの腰痛 一アンケート調査によるプロとアマチュアの比較一
}

$\begin{array}{rrrrl}\text { 横尾 } & \text { 直樹 } & \text { 山本 } & \text { 和良 } & \text { 中村潤一郎 } \\ \text { 本田 } & \text { 淳 } & \text { 上杉 } & \text { 昌章 } & \text { 斎藤 知行 }\end{array}$

Key words ロバレエダンサー（Classical ballet dancer），腰痛（Low back pain）， アンケート (Questionnaire)

要旨：18歳以上の女性ダンサー282名 (プロ109名, アマチュア173名) を対象に, 腰痛 に関するアンケート調査を行った . バレエ歴はプロ 23 年 , アマ 15 年と有意にプロが長 く，週平均レッスン時間はプロ 11 時間，アマ 6 時間，年間舞台回数は光れ艺れ 12 回，2 回と有意にプロが多かった . 腰痛はプロの $92 \%$ ，アマの $84 \%$ に認めた . プロでは光の うち $43 \%$ ガレッスンに支障のある痛みで , 10 \%に休職の経験があった . 腰痛の部位は プロ , アマともに有意に下位腰部, 左側優位が多く, 腰痛を誘発する動作は腰椎伸展 時が最も多かった . 病院, 医院への受診は $10 \%$ と低率であった . プロダンサーはバレ エ歴が長く，十分トレーニングを積んでいるにもかかわらず，アマチュアに比べ休職 率が高いなど腰痛が重度であり，腰背部のoveruseが原因の1つと考えられた . 慢性的 な腰痛や強い腰痛のあるダンサーは, 分離症や疲労骨折などが存在する可能性があり， 整形外科医による検診や，定期的なメディカルチェックなどが必要であると考えた .

\section{Summary}

A questionnaire concerning lower back symptoms was administered to 282 female dancers of classical ballet, over 18 years old. Average hours for training was longer in professionals (11hrs), than in amateurs (6hrs). Number of stage performances was 12 times greater in professional dancers, in comparison with amateur dancers who averaged only 2 performances. Low back pain was found in $92 \%$ of professionals versus in $84 \%$ of amateurs. Out of this $43 \%$ of professionals who reported experiencing that impaired their training exercises, $10 \%$ of professional dancers were unable to dance, on occasion. Both professional and amateur dancers reported that low back pain was most prevalent on the left side of low back. Only $10 \%$ of the dancers visited hospitals for low back pain. The study concluded that the main cause of the low back pain in professional and amateur dancers was due to overuse and overwork. Regular medical examinations and dance education are necessary in order for ballet dancers to minimize the occurrence of chronic low back pain.

Naoki Y OKOO et al : Low back pain of classical ballet dancers

横浜市立大学医学部整形外科学教室〔 


\section{緒 言}

クラシックバレエは, 特に女性に人気が高 い“芸術”である.一見華やかなバレエの世 界は, 厳しい訓練と持久力を要し, 激しいス ポーツに類似した膝関節や足部に高頻度に発 現する整形外科領域のトラブルも少なくな ( ${ }^{9)}$. 欧米諸国ではバレエダンサーの腰痛に ついて多数報告されているが3,4,8)，日本での 実状はあまり知られていない，今回われわれ は, 女性ダンサーの腰痛に関する実態をアン ケート形式で調査し , プロダンサーとアマチ ユアダンサーを比較し，発現頻度や重症度を 中心に検討した .

\section{I . 対象および方法}

首都圏でクラシックバレエを行う 18 歳以 上の女性ダンサー 282 名を対象に，腰痛に関 するアンケート調査を施行した . 対象を，バ レエ団に所属するプロダンサー群 (109名， 以下プロ), バレエ学校またはバレエ教室に 通うアマチュアダンサー群 (173名, 以下ア マ)の2群に分け，個人属性 (年齢, 身長, 体 重), バレ工経験 (バレエ開始年齢, バレエ 歴, 週当たりのレッスン時間, 年間の舞台回 数), 腰痛の有無 (腰痛の経験がない, 過去 にあった，現在もある)を調査した．さらに 腰痛が過去にあったものと現在もあるものを “腰痛あり”とし，腰痛ありと答えた者に対 し，腰痛の程度 (レッスンに支障をきたすか どうか), 腰痛の部位 (臍部以上の上位腰部 か, 臍部以下の下位腰部か, 左右差があるか)， 腰痛を誘発する動作, 腰痛発症時の受診状況， 休職・入院の有無などについて問診した .
表1 個人属性・バレ工経験

\begin{tabular}{lrc}
\hline & \multicolumn{1}{c}{ プロ } \\
& $(\mathrm{n}=63)$ & \multicolumn{1}{c}{$\begin{array}{c}\text { アマ } \\
(\mathrm{n}=134)\end{array}$} \\
\hline 年齢 (歳) & $25.8 \pm 4.5$ & $25.2 \pm 6.8$ \\
身長 $(\mathrm{cm})$ & $160.3 \pm 4.2$ & $158.9 \pm 4.7$ \\
体重 $(\mathrm{kg})$ & $45.5 \pm 2.9$ & $46.6 \pm 4.7$ \\
バレエ開始年齢 (歳) & $5.3 \pm 2.3$ & $9.5 \pm 8.3^{*}$ \\
バレエ歴 (年) & $22.5 \pm 8.9$ & $14.8 \pm 7.0^{*}$ \\
レッスン時間 & $11.1 \pm 6.0$ & $6.4 \pm 4.0^{*}$ \\
舞台回数 (回/年) & $11.9 \pm 9.7$ & $1.8 \pm 1.3^{*}$ \\
\hline$*: \mathrm{P}<0.05$ & & (mean $\pm \mathrm{SD})$
\end{tabular}

\section{II. 結 果}

未回収, 記載不備を除いた有効回答は 197 名 $(69.9 \%)$ から得られた . 各群の有効回答 率はプロ $64.9 \%$ ，アマ $72.4 \%$ であった .

平均年齢はプロ 25.8 歳, アマ 25.2 歳, 身長 はプロ $160.3 \mathrm{~cm}$, アマ $158.9 \mathrm{~cm}$, 体重はプロ $45.5 \mathrm{~kg}$, アマ $46.6 \mathrm{~kg}$ で, 両群間の個人属性 に有意な差を認めなかった . 平均バレエ開始 年齢はプロ 5.3 歳, アマ9.5歳, バレエ歴はプ 口 22.5 年, アマ 14.8 年とプロが有意に長かっ た。また，週当たりの平均レッスン時間はプ ロ 11.1 時間, アマ 6.4 時間, 年間の舞台回数 はプロ 11.9 回, アマ1.8回とプロが有意に多 かった(表1).また , プロダンサーのプロ転 向後の年数は平均 6.0 年であった .

腰痛ありと答えたものは, プロ $92.1 \%$, ア マ $83.6 \%$ \%ほととどのダンサーが腰痛を経験 していた . 現在もありはプロ $44.4 \%$ ，アマ $32.8 \%$ とプロが多い傾向にあった (図1). 腰 痛ありのうちレッスンに支障をきたす腰痛 は, プロの $42.6 \%$, アマの $18.1 \%$ に認め, プ 口の方が重度であった(図2). 腰痛の部位は， 下位腰部痛がプロの $63.8 \%$, アマの $59.4 \%$ と 半数以上であった . また , プロの $56.9 \%, ア$ マの 35.7 \%で腰痛に左右差を認め, 光のうち 


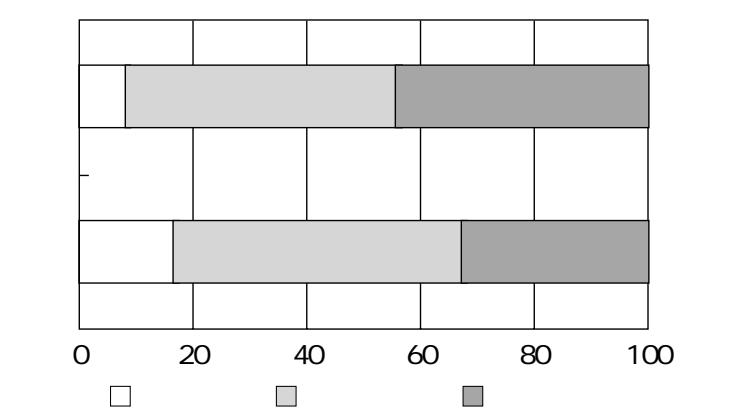

図1 腰痛の有無

“過去にあり”はプロ $47.7 \%$, アマ $50.8 \%$ “現在も あり”はプロ $44.4 \%$ ，アマ $32.8 \%$ で，ほとんどのダ ンサーが腰痛を経験していた。

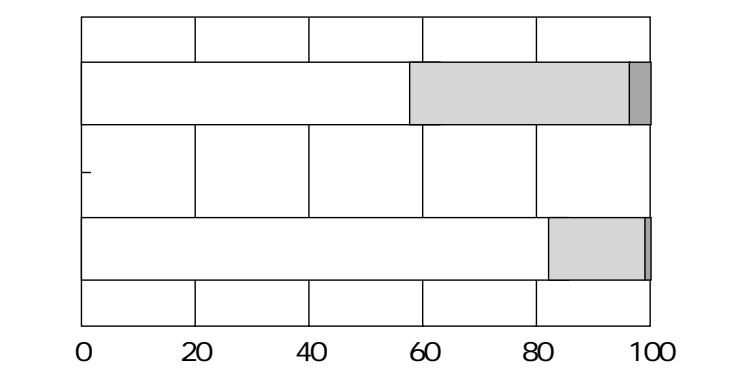

ロレッスンには支障がない $\square$ なとかレッスンできる $\square$ 時々休㮃が必要

\section{図 2 腰痛の程度}

腰痛ありのうち“なんとかレッスンできる”はプロ $38.9 \%$ ，アマ $17.1 \%$,“時々休鄎が必要”はプロ $3.7 \%$ ，アマ $1.0 \%$ であつた .

左側優位の腰痛がプロの $90.9 \%$, アマの $77.5 \%$ を占めた (図 3) . 腰痛を誘発する動作 は腰椎伸展時が最も多く，プロの $30.4 \% ， ア$ マの $34.1 \%$ を占め，次いで回転動作やジャン プの着地時が多かった (図4). 弚の他では特 定の動作で痛むのではなく，舞台前にレッス ン量が増加すると痛むという答えが多かっ た。

腰痛発症時には整体，マッサージ，鍼负院 を受診するダンサーが多く，プロの $80.2 \% ，$ アマの $61.0 \%$ を占めた . 病院 , 医院への受診 はプロ，アマとも $10 \%$ と非常に低率であっ た (図 5) . 腰痛による休職, 入院はプロの
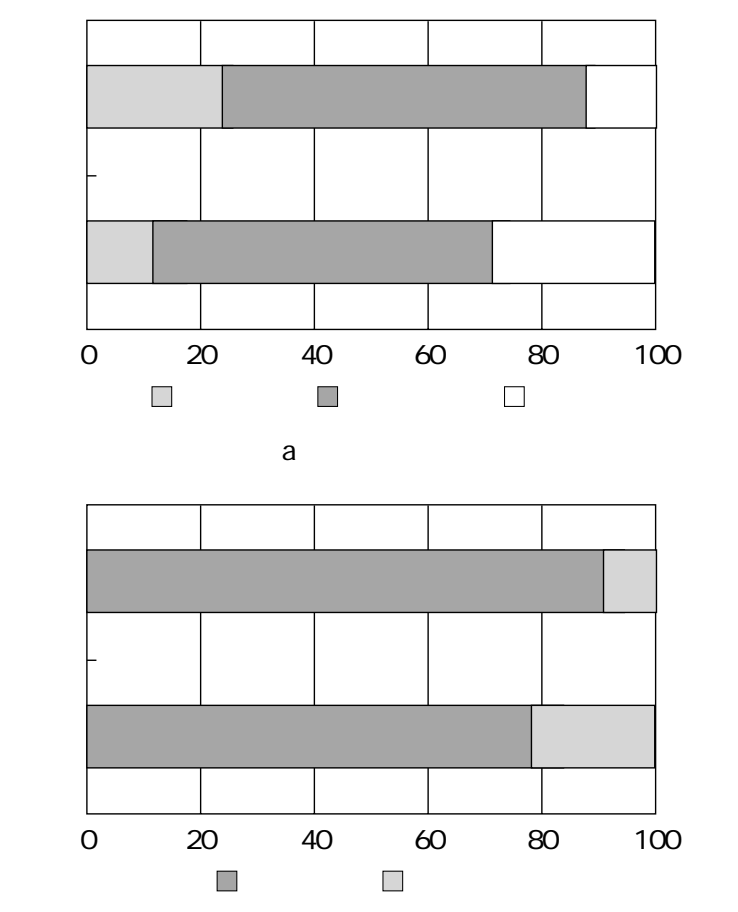

b 左右差

図3 腰痛の部位

(a) 上位腰部痛がプロの $24.1 \%$, アマの $11.5 \%$,下 位腰部痛がプロの $63.8 \%$ ，アマの $59.4 \%$ であった .

(b) プロの $56.9 \%$, アマの $35.7 \%$ で腰痛に左右差を 認め, 炎のうちプロの 90.9 \%アマの $77.5 \%$ が左側優 位の腰痛であった .

$10.3 \%$ ，アマの $4.5 \%$ に認め , プロがより重 篤であった . 腰痛に対する手術はプロ , アマ ともに1例ずつであった .

$$
\text { IV.考 察 }
$$

クラシックバレエは，舞踏活動の中で高強 度の身体活動に分類されており, 跳躍や回転 動作を伴う運動強度の高い身体移動が行われ る7). バレエの動作特性には下肢の外転を維 持しながらの動きや足部底屈位での身体の姿 勢保持などがあげられる .プリエは, 股関節 を外旋し膝蓋骨と足部を外方に向けて膝関節 を屈曲する動作で, ジャンプの踏み切りや着 


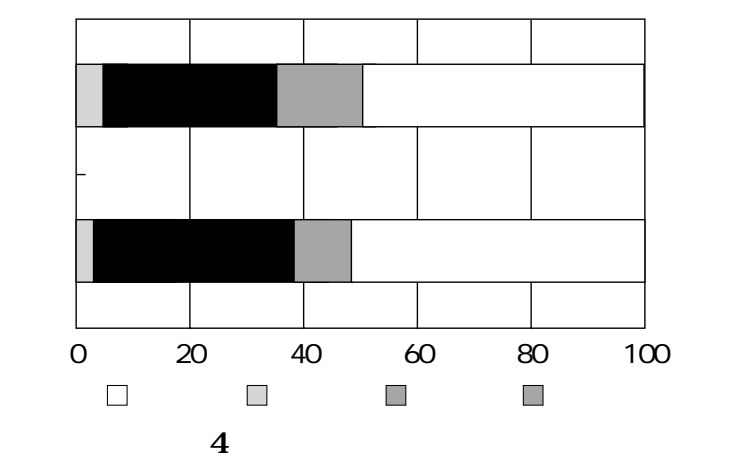

腰痛を誘発する動作は, 腰椎伸展時がプロの $30.4 \%$ ， アマの $34.1 \%$ を占め最も多かった．次いで回転動作 やジャンプの着地時が多くプロの $15.9 \%$ ，アマの $11.4 \%$ であった .

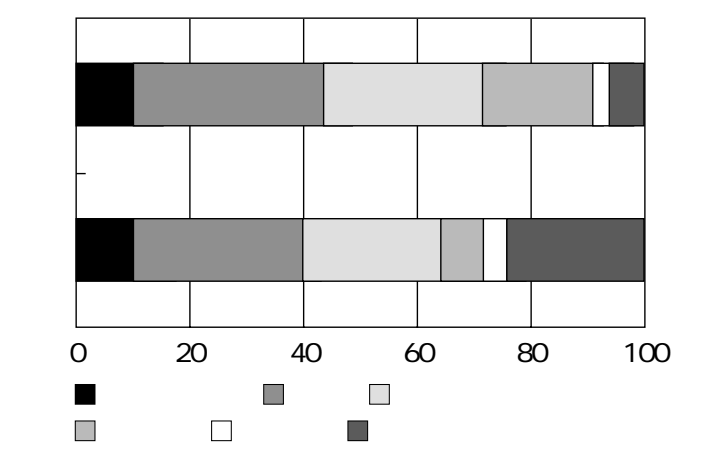

図 5 腰痛発症時の受診状況

腰痛発症時には整体，マッサージ，銊负院を受診す るダンサーが大半を占めた . 病院 , 医院への受診は プロの $10.4 \%$, アマの $10.5 \%$ と非常に低率であった .

地，回転，さまざまな動作のつなぎで使うバ レエの基本の肢位である . バレエは荷重負荷 が体幹と下肢に限定した動作樣式であるた め，このような基本技術が完璧でないと怪我 に直結することがある．

バレエ特有の腰背部を前後屈する基本姿勢 にポール・ドゥ・ブラやカンブレ , アラベス クという動作がある . アラベスクは胸腰椎を 伸展し下肢を後方に挙上するポーズで, 腰背 部筋の強く持続的な収縮を要する . 胸腰椎全 体の伸展により緩いカーブを描くのが正しい 姿勢であるが, 下位腰椎のみで伸展すると腰

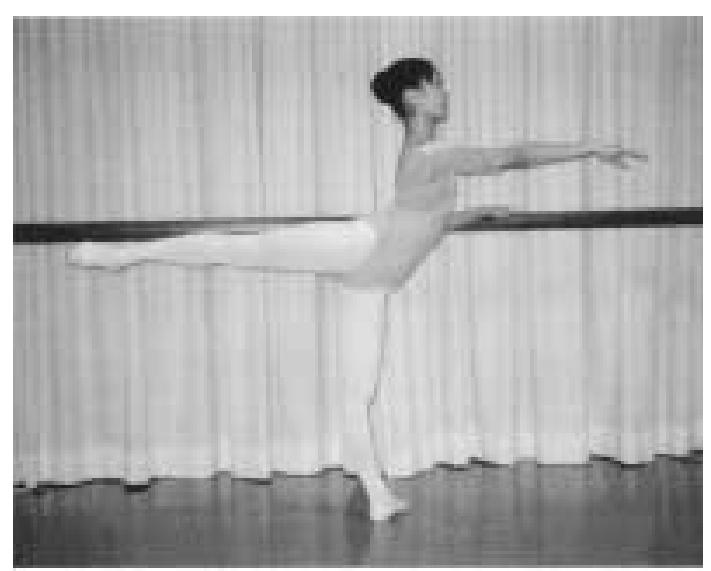

(a) 正しいアラベスク

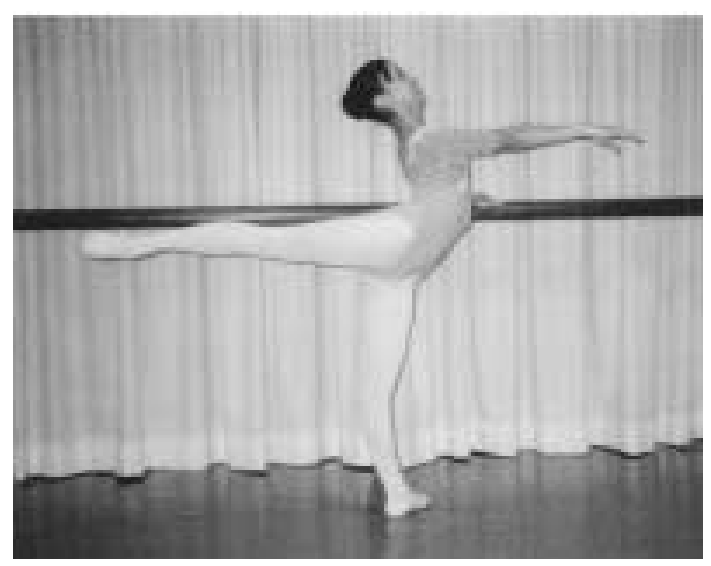

(b) 誤ったアラベスク

図6 アラベスクのポーズ

アラベスクは腰椎を伸展する基本姿勢の1つである . (a) では胸腰椎全体で伸展しているが，(b)では下位 腰椎のみで伸展している .

部に過剩な負担がかかる(図6). 蘆田ら ${ }^{2)}$ は， バレエ学校の生徒に対する調査を行い, 腰痛 を認めた 6 名中 4 名は下位腰椎部のみで伸展 するアラベスクで筋性腰痛を発症し, 兴の癖 をなおすことで症状が軽快したと報告した． 今回の調査でも, 腰部伸展位で腰痛か誘発さ れるケースが多く，このようなテクニックの 誤りも原因の1つと考えられた .

しかしながら，技術的に成熟したプロダン サーでも 30 \%が腰部伸展位で腰痛を生じた 


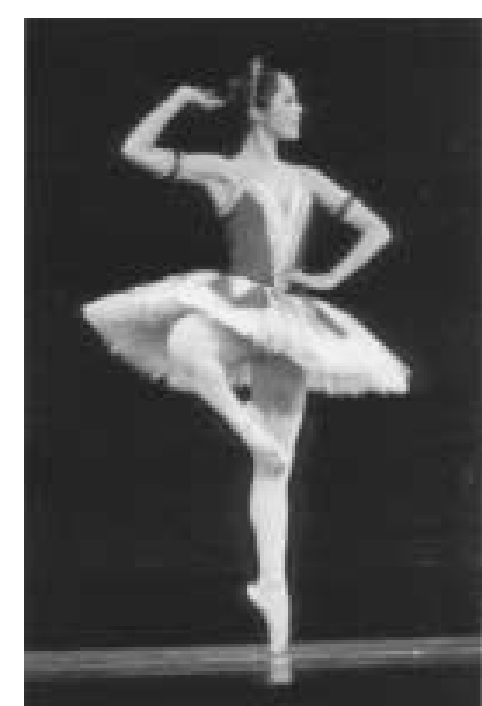

図7 左下肢を軸としたパッセのポーズ 舞台では, ピルエットやフェッテとい った回転系の連続動作は左下肢を軸に することが多い。

と答えた . Micheli ら ${ }^{8)}$ はバレエダンサーの 11〜20\%に腰椎分離症を認め，一般コーカ サス人女性の数倍の発症率であると報告して いる.また，椎弓や椎間関節の疲労骨折につ いての報告も散見し，腰椎の反復的な過伸展， 過屈曲が原因と考えられている ${ }^{1,5,6)}$.これら のことから，慢性的な腰痛のあるダンサーに は, 分離症や疲労骨折などが存在する可能性 があり，整形外科医による検診とさらにX線 撮像やCT撮影が必要と思われた .

また, 回転動作やジャンプの着地時に腰痛 が誘発されるという回答を $15 \%$ に認めた . 着地時は足先, 足関節, 膝関節の順にショッ クを吸収しながらプリエの形で着地する . 技 術が末熟であったり，疲労や下肢の筋力不足 でショックを吸収できない場合, 腰部や骨盤 部に多大な負担がかかり腰痛が生じると考え られた 。

腰痛発症部位では, 部位に左右差があるダ
ンサーの多くが左側優位の腰痛で, 特にプロ ダンサーは $90 \%$ が左側を占めた .ピルエッ トやフェッテといった回転系の連続動作は， 特に舞台では左下肢を軸にすることが多いた め, 腰部への負担が偏り左側優位な腰痛を生 じると考えられた (図 7). 左右のバランス良 くトレーニングを行うことが望まれる .また， プロダンサーはバレエ歴が長く, 十分トレー ニングを積んでいるにもかかわらず, アマチ ユアに比べ休職率が高いなど腰痛が重度であ つた . プロの平均レッスン時間はアマの約 2 倍, 舞台回数は 6 倍であることから, 腰背部 のoveruseが原因と考えられ，なるべく過剩 なレッスンを避けるとともに，適度な休息と， 腹筋群, 背筋群の筋力増強も必要と思われ た。

医療機関への受診率は非常に低く，特に慢 性的な腰痛や強い腰痛のあるダンサーは, 整 形外科への受診や定期的なメディカルチェッ クなどが必要であり，今後ダンサーたちが長 く踊り続けていくために医療面での支援が必 須である .

\section{文献}

1) Abel MS. Jogger's fracture and other stress fractures of the lumbo-sacral spine. Skeletal Radiol. 1985; 13:221-227.

2) 蘆田ひろみ, 富永通裕, 河合稔之ほか. 筋性腰 痛一バレエダンサーと女子体操選手の例を中心 として一。臨床スポーツ医学 . 1988 ; 5 ：245250.

3) Bejjani FJ. Occupational biomechanics of athletes and dancers: A comparative approach. Clin Podiatr Med Surg. 1987 ; 4 :671-711.

4) Bryan N, Smith BM. The ballet dancer. Occup Med. $1992 ; 7: 67-75$.

5) Fehlandt Jr AF, Micheli LJ. Lumbar facet stress fracture in a ballet dancer. Spine. $1993 ; 18$ : 2537-2539.

6) Ireland ML, Micheli LJ. Bilateral stress fracture of the lumber pedicles in a ballet dancer. J Bone 
Joint Surg. 1987 ; 69-A : 140-142.

7) McNitt-Gray JL, Koff SR, Hall BL. The influence of dance training and foot position on landing mechanics. Med Plobl Perform Art. 1992 ; 7 : 8791.
8) Micheli LJ. Back injuries in dancers. Clin Sports Med, 1983;2:473-484.

9) 小川正三, 崎原 宏, 三須一雄 : クラシックバ レエダンサーの足の愁訴について . 足の外科研 究会誌. $1987 ; 8: 3-5$. 